\title{
Assessment of long-term treatment results in women suffering from anorexia nervosa in adolescence
}

Ocena odległych wyników leczenia kobiet chorujących w okresie adolescencji na jadłowstręt psychiczny

\author{
${ }^{1}$ Magdalena Wszołek, ${ }^{2}$ Karolina Ziora-Jakutowicz, ${ }^{3}$ Piotr Gorczyca, ${ }^{4}$ Katarzyna Rojewska, \\ ${ }^{5}$ Katarzyna Ziora
}

${ }^{1}$ Individual Specialist Medical Practice, Poland

${ }^{2}$ Department of Genetics, Institute of Psychiatry and Neurology, Warsaw, Poland

${ }^{3}$ Department of Psychiatry, Faculty of Medical Sciences in Zabrze, Medical University of Silesia in Katowice, Poland

${ }^{4}$ Pediatric Endocrinology, Public Clinical Hospital No.1 in Zabrze, Poland, Polska

${ }^{5}$ Department of Paediatrics, Faculty of Medical Sciences in Zabrze, Medical University of Silesia in Katowice, Poland

\begin{abstract}
Introduction: Reports assessing long-term treatment outcomes for anorexia nervosa (AN) are divergent and refer to different populations. They lack long-term observations in AN patients in Poland.

Aim of the study: Analysis of the recovery, relapse rate, and predictive factors in patients treated due to AN in adolescence.

Material and methods: A total of 201 subjects were given a survey. Ninety-seven women were recruited: 56 reported to the clinic and 41 filled in the survey.

Results: The average period from hospitalization to the survey was $7.76 \pm 4.39$ years. Remission was found in $78.4 \%$, $21.6 \%$ still presented AN, and $84.2 \%$ required a one-off hospitalisation, $10.5 \%$ twice. The average BMl was: $20.08 \pm 3.24 \mathrm{~kg} / \mathrm{m}^{2}$. The rate of attempted suicides was $6.2 \%$. Predictive factors for poor outcome were as follows: older age of the patient when falling ill, lower SDS-BMI score at the onset of AN, transition from the restrictive type of AN into a binge-eating/purging type, and failure to maintain contact with the mother.

\section{Conclusions:}

1. Most girls suffering from the restricting type of AN in adolescence are cured permanently.

2. The severity of symptoms in these girls does not eliminate the chance of recovery and achieving important life goals, completing education, finding a life partner, and having children.

3. Girls with a smaller degree of cachexia at onset of AN, with no binge-eating/purging symptoms, maintaining regular contact with their mothers, have a better prognosis for recovery.

4. Six per cent of women treated in their youth for AN face the risk of attempted suicide, which points to the need to monitor their mental state for many years.
\end{abstract}

\section{Key words:}

anorexia nervosa, long-term observation, predictive factors.

\section{Streszczenie}

Wprowadzenie: Doniesienia oceniające odległe wyniki leczenia jadłowstrętu psychicznego (anorexia nervosa - AN) są rozbieżne i dotyczą różnych populacji. Brakuje długofalowych obserwacji na ten temat u chorych z AN w Polsce.

Cel pracy: Analiza odsetka wyleczeń, nawrotów i próba ustalenia czynników prognostycznych u chorych leczonych z powodu AN w okresie adolescencji.

Materiał i metody: Do 201 kobiet leczonych z powodu AN wysłano ankietę skonstruowaną na potrzeby badania. Zrekrutowano 97 kobiet: 56 zgłosiło się do kliniki, a 41 kobiet wypełniło ankietę. 
Wyniki: Średni czas od hospitalizacji do momentu badania wynosił 7,76 $\pm 4,39$ roku. Remisję stwierdzono u 78,4\%, 21,6\% kobiet nadal miało objawy AN. Większość kobiet w remisji (84,2\%) wymagała jednorazowej hospitalizacji, 10,5\% dwukrotnej. Średni wskaźnik masy ciała (body mass index - BMI) badanych po latach wynosił 20,08 $\pm 3,24 \mathrm{~kg} / \mathrm{m}^{2}\left(13,6-37,2 \mathrm{~kg} / \mathrm{m}^{2}\right)$. Odsetek prób samobójczych wynosił 6,2\%. Predyktorami złego rokowania były: starszy wiek pacjentki w chwili zachorowania, większy stopień wyniszczenia i niższy wskaźnik SDS-BMI na początku choroby, zmiana postaci restrykcyjnej AN w postać bulimiczno-oczyszczającą, nieutrzymywanie kontaktu z matką.

\section{Wnioski:}

1. Większość dziewcząt chorujących na postać restrykcyjną jadłowstrętu psychicznego w okresie adolescencji ulega wyleczeniu.

2. Znaczne nasilenie objawów choroby nie przekreśla szansy na wyleczenie i osiągnięcie istotnych celów życiowych: ukończenia edukacji, znalezienia partnera życiowego i posiadania potomstwa.

3. Na lepsze rokowanie co do wyleczenia mogą liczyć dziewczęta z mniejszym stopniem wyniszczenia na początku choroby, bez objawów bulimiczno-oczyszczających, utrzymujące stały kontakt z matką.

4. Około 6\% kobiet leczonych w młodości z powodu AN jest zagrożonych próbą samobójczą, co wskazuje na konieczność monitorowania stanu psychicznego tych kobiet przez wiele lat.

Słowa kluczowe:

anorexia nervosa, długoterminowa obserwacja, czynniki prognostyczne.

\section{Introduction}

Anorexia nervosa (AN) is an eating disorder, consisting of the patient's striving to lose weight, and their distorted perception of their own appearance, accompanied by a fear of gaining weight (DSM-5) [1]. This leads to considerable restrictions in food intake, excessive physical exercise, and/or purging behaviours (vomiting, laxatives, diuretics).

The peak incidence of AN is in the age range 14-18 years, and in ca. $85 \%$ of cases it happens before the age of 20 . In recent years, the incidence of AN has increased, particularly in women in the age range 15-24 years [2-4]. The course of the disease may be episodic, although much more frequently it is chronic in nature, with periods of remission and relapse. AN may cause numerous complications from multiple organs. Even in the case of only one episode of the disease in adolescence, the effects of the disease may persist into adulthood.

The available subject literature provides works evaluating long-term treatment outcomes in patients suffering from anorexia nervosa with the onset of the disease in their childhood [5-13], as well as meta-analyses pertaining to research in this field in women with AN treated in the $20^{\text {th }}$ century $[14,15]$. It lacks, however, long-term observations of AN patients in the Polish population.

Identification of predictive factors through the indication of patients presenting with an increased risk of relapses and complications, and consequently with a worse final prognosis, may be beneficial for treatment optimisation. Therefore, it seems advisable to conduct an analysis of the long-term condition of patients treated for anorexia nervosa in their childhood.

\section{Aim of the study}

An analysis of the percentage of recoveries, relapses of the disease, and further lives of patients treated for anorexia nervosa in adolescence, and an attempt to determine the predictive factors for such patients.

\section{Material and methods}

The study was approved by the Bioethics Committee of the Medical University of Silesia in Katowice (KNW/0022/KB1/3/11 dated 18.01.2011).

The study initially covered 201 subjects (192 females and 9 males) treated for the restricting type of anorexia nervosa [1] at the Paediatric Endocrinology Department of Independent Public Clinical Hospital No. 1 in Zabrze, Poland in 1990-2012. Personal data of the patients and details concerning their disease, test results, and therapy were defined based on their medical history kept in the hospital archives. In order to carry out the study, a survey was compiled, consisting of 16 questions relating to the patient after their coming of age, including the following: the course of the disease, recurrent hospitalisations, continuation of the outpatient and/or inpatient treatment, psychotherapy, somatic and/or mental complications, menstruation return, use of medications, slimming agents, stimulants, excessive physical exercise, and addictions. The subjects were asked about their current body mass and height. Other questions referred to their family life, offspring, contact with their parents, their parents' education, further education, and the patients' occupation.

All the patients who had been initially qualified for the study were sent a letter with an invitation to take part in the study and asked to send back completed surveys or to report to the clinic. It was also decided to obtain some information about the AN patients from their parents if the patients had left the country or died.

Eventually, 97 females and 2 males were recruited. The men were excluded from the further study due to their small number. The entire group of females qualified for the study ( $E G=$ entire group) was divided into the following: a group of 41 women who limited their participation to sending back the completed survey (surveyed group $=\mathrm{SG}$ ), and a group of 56 women who completed the survey and reported to the clinic personally (investigated group $=\mid \mathrm{G}$ ). Subjects from the investi- 
gated group were subjected to the assessment of their somatic condition along with the measurement of their body mass and body mass index (BMI).

The variables analysed during the study were as follows: age and degree of cachexia as of admission to hospital, duration of the disease prior to hospitalisation, duration of hospitalisation, number of relapses, attending psychotherapy, education, career, having children, and contact with siblings and parents.

In compliance with DSM-5 [1], a full remission of the disease was regarded as the lack of fulfilment of all AN diagnostic criteria for a long time, in a situation where all the criteria had been fulfilled in the past. Additionally, the recovery criteria included the return of menstruation and no further indications for psychotherapy, following the definitions of the AN remission applied by other authors [16].

\section{Statistical methods}

A relevant database was prepared in a spreadsheet in Microsoft Excel. Statistical calculations were carried out in MedCalc ver. 18.2.1. The statistical calculations assumed the level of statistical significance to be $a=0.05$. The following descriptive statistics were calculated for all the numerical variables: arithmetic mean, median, minimum value, maximum value, lower and upper quartile, standard deviation (SD), statistical error (SEM), variance, and 95\% confidence interval around the mean and median. The compliance of their distribution with the normal distribution was checked. The compliance assessment applied the D'Agostino-Pearson test. Variance homogeneity was verified by means of Levene's test. The significance of differences in mean values for unrelated variables with a distribution other than normal or in heterogeneous variances was verified by means of the Mann-Witney nonparametric test. Test results were presented in a graphic form in box plots and cumulative graphs with error bars plotted (95\% confidence intervals for the median). An analysis of multiple-way tables was carried out for qualitative variables. Pearson's $\chi^{2}$ test was conducted, and the contingency coefficient was calculated as a measure of dependence between variables. For the purposes of predictive factors, the odds of an occurrence of a given health phenomenon and the odds ratio were calculated for comparable groups. Furthermore, an analysis of logistic regression was performed for the purposes of assessing the effect of a selected group of variables onto the dichotomous variable assessing a particular patient's health. An analysis of Spearman's rank correlation was performed. The correlation coefficient $R$ and the level of significance of correlation coefficients were calculated. The results were presented in scatter graphs with the regression line and 95\% confidence intervals for regression and prediction plotted.

\section{Results}

In the group of all patients suffering from anorexia nervosa hospitalised in the Paediatric Clinic in Zabrze between 1990 and 2012, girls constituted $95.52 \%$, and boys 4.48\%, which means that girls with AN were hospitalised 21 times more often than boys with AN.

Out of all 201 AN patients to whom an invitation letter had been sent, only $50.5 \%$ of women and $22.2 \%$ of men participated in the study by returning a completed survey or contacting the authors by phone. Out of the 97 women participating in the study (EG), the majority, i.e. 56 women (57.7\%), reported personally in the clinic (IG), and 41 women (42.3\%) limited their participation to posting a completed survey only (SG).

Tests were not performed on all the hospitalised patients for the following reasons: change of address or telephone number, having left Poland, reluctance to take part in the test on the part of former patients or their parents, and death. Twenty-one (10.4\%) letters with an invitation to take part in the study were returned by post due to a wrong address, and 71 (35.53\%) were not returned for unknown reasons. Three women (1.5\%) notified the authors on the phone that they would not take part in the study because they did not want to evoke traumatic memories of their hospitalisation and that they were healthy at the time. Two parents said that their daughters would not take part in the study because they were abroad. One mother also informed us on her daughter's death due to acute cardiac complications related to AN. It was a 16-year-old patient, who had not been reporting to check-ups after discharge and had not been treated for more than 10 months. Another girl (age: 15 years) died during re-hospitalisation during a surgery due to gastric necrosis, after having been transferred to the Psychiatric Ward due to catatonia.

The characteristics of the groups of investigated women are given in Tables I and II.

The investigated group (IG) did not differ significantly statistically from the surveyed group (SG) in terms of body mass, VBMI, and BMI-SDS, both during hospitalisation in the clinic and at the time of the study (Tables I and II).

The average time between hospitalisation and the time of the study was $7.76 \pm 4.39$ (Table II). The average age of the women as of the time of the study was $23.07 \pm 4.28$, average body mass: $54.74 \pm 10.67 \mathrm{~kg}$, average height: $164.7 \pm 5.96 \mathrm{~cm}$, average BMI: $20.08 \pm 3.24 \mathrm{~kg} / \mathrm{m}^{2}$. It was demonstrated that the weight gain observed in the subjects since their hospitalisation was on average $15.22 \pm 11.24 \mathrm{~kg}$, and the average height gain was $3.72 \pm 5.13 \mathrm{~cm}$, whereas the difference between the BMl calculated during the study and the BMI from the period of hospitalisation was on average $4.92 \pm 3.82 \mathrm{~kg} / \mathrm{m}^{2}$. The standard deviation for BMI (BMI-SDS) was also assessed, and during the study it was on average $-0.49 \pm 1.59$, whereas the difference between the current BMI-SDS and the BMI-SDS during hospitalisation was on average $2.23 \pm 1.95$ (Table II).

Based on the information obtained in the surveys and during examinations performed in the clinic, it was determined that in the entire group of 97 women the recovery rate was $78.4 \%$ (76 women). On the other hand, 21.6\% (21 women) still suffered from anorexia nervosa (Table III).

Out of the group of women who had reported personally to the clinic (IG), 14 (1.4\% of this group) confirmed they were still suffering from AN. Such individuals constituted $14.3 \%$ of the 
Table I. Characteristic of the groups of women examined at the time of diagnosis of anorexia nervosa (data from the period of childhood hospitalization obtained from the history of the disease)

\begin{tabular}{llll}
\hline Parameter & $\begin{array}{l}\mathrm{GC} \\
(n=97) \\
\text { average } \pm \mathrm{SD} \\
(\text { Min.-Max.) }\end{array}$ & $\begin{array}{l}\text { GB } \\
(n=56) \\
\text { average } \pm \mathrm{SD} \\
(\text { Min.-Max.) }\end{array}$ & $\begin{array}{l}\text { GA } \\
(n=41) \\
\text { average } \pm \text { SD } \\
(\text { Min.-Max.) }\end{array}$ \\
\hline Age (years) & $\begin{array}{l}15.31 \pm 1.5 \\
(11.5-17.8)\end{array}$ & $\begin{array}{l}15.45 \pm 1.55 \\
(11.5-17.8)\end{array}$ & $\begin{array}{l}15.11 \pm 1.42 \\
(12.2-17.5)\end{array}$ \\
\hline Weight $(\mathrm{kg})$ & $39.51 \pm 6.31$ & $39.96 \pm 6.86$ & $38.90 \pm 5.5$ \\
& $(25-56.9)$ & $(28-56.9)$ & $(25-52.1)$ \\
\hline Growth $(\mathrm{cm})$ & $161.01 \pm 6.26$ & $160.63 \pm 6.44$ & $161.52 \pm 6.05$ \\
& $(143.5-175)$ & $(143.5-172)$ & $(148-175)$ \\
\hline BMI $\left(\mathrm{kg} / \mathrm{m}^{2}\right)$ & $15.16 \pm 2.07$ & $15.37 \pm 2.14$ & $14.88 \pm 1.96$ \\
& $(11.3-21.7)$ & $(11.3-21.7)$ & $(11.4-21.02)$ \\
\hline BMI-SDS & $-2.73 \pm 1.18$ & $-2.67 \pm 1.15$ & $-2.80 \pm 1.22$ \\
& $(-5.58-0.611)$ & $(-5.58-0.611)$ & $(-5.2-0.29)$ \\
\hline Cole's Index (\%) & $75.74 \pm 10.13$ & $76.38 \pm 10.38$ & $74.88 \pm 9.85$ \\
& $(55-105)$ & $(55-105)$ & $(55-100)$ \\
\hline The duration of amenorrhoea & $8.97 \pm 6.41$ & $9.55 \pm 6.93$ & $8.21 \pm 5.66$ \\
before hospitalization (months) & $(3-36)$ & $(3-36)$ & $(3-36)$ \\
\hline
\end{tabular}

$\mathrm{GC}$ - the whole group of patients with anorexia nervosa $(\mathrm{GC}=\mathrm{GB}+\mathrm{GA})$; $\mathrm{GB}$ - study group; $\mathrm{GA}$ - surveyed group

entire group (EG). In the group of 41 individuals whose details on recovery from AN derived only from the survey (SG), 7 women $(17.1 \%)$ stated they were still suffering from AN (Table III).

In 3 women excessive body mass was observed after years. Two were overweight (average BMl: $27.7 \mathrm{~kg} / \mathrm{m}^{2}$ ), and one was obese (BMl: $37.2 \mathrm{~kg} / \mathrm{m}^{2}$ ).

Most frequently, women in remission had required a one-off hospitalisation due to anorexia nervosa (84.2\% of the women). $10.5 \%$ of the women had required 2 hospitalisations. Women who were considered as having recovered from AN had required $1-3$ hospitalisations, and $5.3 \%$ of them had been admitted to hospital 3 times due to this disease. The average hospitalisation duration had been 1.25 months, i.e. 5 weeks in all the women.

On the basis of the surveys, it was determined that 45 women, i.e. half of all the girls hospitalised in the clinic (46.4\% of the study subjects), had been reporting for 15 months on average for outpatient check-ups after discharge. This group included 33 cured women and 12 women who were still sick. Six girls were treated in the Psychiatric Outpatient Clinic right after hospitalisation, for 33.5 months on average. Four of them still suffer from AN. Five study subjects were under the care of a Psychological Outpatient Clinic after discharge, out of which 3 have recovered and 2 are still sick. The average period of check-ups in the Psychological Outpatient Clinic was 18 months, with 30 months on average in the case of patients who remain sick, and 9 months on average in the currently healthy study subjects. Thirty-one women (31.9\% of the study subjects) had not been under the care of any outpatient clinic after discharge. Twenty-eight women in this group are healthy, and 3 are still sick.

According to the survey data obtained from all the study subjects, it was determined that 34 of them, i.e. $35.4 \%$, had experienced complications after discharge, which comprised menstrual disorders and mental disorders. Persistent menstrual disorders concerned 12 women, i.e. $12.4 \%$ of the study subjects. On the other hand, unspecified mental disorders were reported by 10 women (10.3\%), of whom a half are still suffering from anorexia nervosa. Six women admitted to attempting suicide, which constitutes $6.2 \%$ of all the 97 study subjects. The average number of suicide attempts undertaken by all the studied women was 1.6.

A twice as high number of suicide attempts was observed in the group of subjects still suffering from AN, as compared to the ones who had recovered.

Other AN complications, besides the ones mentioned above, were reported by 20 women (20.6\% of EG). Eleven women are currently on psychotropic medication, and 19 women take hormonal drugs. Ten women reported they were taking other medications. None of the study subjects declared taking any vitamins or dietary supplements. 
Table II. Characteristic of the groups of studied women (data obtained on the basis of questionnaires and/or physical examination conducted prospectively years after hospitalization due to anorexia nervosa)

\begin{tabular}{|c|c|c|c|}
\hline Parameter & $\begin{array}{l}\mathrm{GC} \\
(n=97) \\
\text { average } \pm \mathrm{SD} \\
\text { (Min.-Max.) }\end{array}$ & $\begin{array}{l}\mathrm{GB} \\
(n=56) \\
\text { average } \pm \mathrm{SD} \\
\text { (Min.-Max.) }\end{array}$ & $\begin{array}{l}\text { GA } \\
(n=41) \\
\text { average } \pm \text { SD } \\
\text { (Min.-Max.) }\end{array}$ \\
\hline $\begin{array}{l}\text { Time since hospitalization } \\
\text { (years) }\end{array}$ & $\begin{array}{l}7.76 \pm 4.39 \\
(1-21)\end{array}$ & $\begin{array}{l}7.08 \pm 4.47 \\
(0.7-16.6)\end{array}$ & $\begin{array}{l}8.7 \pm 4.14 \\
(1.8-21)\end{array}$ \\
\hline Age (year) & $\begin{array}{l}23.07 \pm 4.28 \\
(14-34)\end{array}$ & $\begin{array}{l}22.53 \pm 4.11 \\
(16.3-31)\end{array}$ & $\begin{array}{l}23.8 \pm 4.44 \\
(14-34)\end{array}$ \\
\hline Weight (kg) & $\begin{array}{l}54.74 \pm 10.67 \\
(31.5-114)\end{array}$ & $\begin{array}{l}53.85 \pm 12.06 \\
(31.5-114)\end{array}$ & $\begin{array}{l}55.95 \pm 8.4 \\
(40-85)\end{array}$ \\
\hline Weight gain (kg) & $\begin{array}{l}15.22 \pm 11.24 \\
(-11.9-73.3) \\
\end{array}$ & $\begin{array}{l}13.89 \pm 12.26 \\
(-11.9-73.3)\end{array}$ & $\begin{array}{l}17.05 \pm 10.01 \\
(-2.4-52.7)\end{array}$ \\
\hline Growth (cm) & $\begin{array}{l}164.73 \pm 5.96 \\
(152-177)\end{array}$ & $\begin{array}{l}163.53 \pm 6.32 \\
(152-177)\end{array}$ & $\begin{array}{l}166.37 \pm 5.05 \\
(157-177)\end{array}$ \\
\hline Height gain (cm) & $\begin{array}{l}3.72 \pm 5.13 \\
(0-32.5)\end{array}$ & $\begin{array}{l}2.9 \pm 5.19 \\
(0-32.5)\end{array}$ & $\begin{array}{l}4.84 \pm 4.89 \\
(0-20)\end{array}$ \\
\hline $\mathrm{BMI}\left(\mathrm{kg} / \mathrm{m}^{2}\right)$ & $\begin{array}{l}20.08 \pm 3.24 \\
(13.6-37.2)\end{array}$ & $\begin{array}{l}20.01 \pm 3.6 \\
(13.6-37.2)\end{array}$ & $\begin{array}{l}20.17 \pm 2.72 \\
(14.1-29.7)\end{array}$ \\
\hline BMI difference $\left(\mathrm{kg} / \mathrm{m}^{2}\right)$ & $\begin{array}{l}4.92 \pm 3.82 \\
(-4.5-23.1)\end{array}$ & $\begin{array}{l}4.65 \pm 4.02 \\
(-4.5-23.1)\end{array}$ & $\begin{array}{l}5.29 \pm 3.54 \\
(-2.26-18.3)\end{array}$ \\
\hline BMI-SDS & $\begin{array}{l}-0.49 \pm 1.59 \\
(-4.23-5.23)\end{array}$ & $\begin{array}{l}0.61 \pm 1.63 \\
(-4.23-3.05)\end{array}$ & $\begin{array}{l}-0.33 \pm 1.55 \\
(-3.55-5.23)\end{array}$ \\
\hline BMI-SDS difference & $\begin{array}{l}2.23 \pm 1.95 \\
(-2.72-10.43)\end{array}$ & $\begin{array}{l}2.05 \pm 1.79 \\
(-2.72-5.94)\end{array}$ & $\begin{array}{l}2.48 \pm 2.15 \\
(-1.40-10.43)\end{array}$ \\
\hline
\end{tabular}

$\mathrm{GC}$ - the whole group of patients with anorexia nervosa (GC = GB + GA); GB - study group; GA - surveyed group; weight gain - the difference between actual weight and weight during hospitalization; height gain - the difference between the actual height and the height during hospitalization; BMI difference - the difference between the current BMI and the BMI during hospitalization; SDS-BMI difference - the difference between the current BMI-SDS and BMI-SDS during hospitalization

Table III. The current health condition of the examined women (according to the survey)

\begin{tabular}{lllll}
\hline & $\begin{array}{l}\text { Number still suffering } \\
\text { from AN }\end{array}$ & Interest (\%) & Number cured & Interest (\%) \\
\hline $\begin{array}{l}\text { The whole group (GC) } \\
n=97\end{array}$ & 21 & $21.6 \%$ GC & 76 & $78.4 \%$ GC \\
\hline $\begin{array}{l}\text { Study group (GB) } \\
n=56\end{array}$ & 14 & $14.3 \%$ GC & 42 & $4.3 \%$ GC \\
\hline $\begin{array}{l}\text { Surveyed group (GA) } \\
n=41\end{array}$ & 7 & $25 \%$ GB & $75 \%$ GB \\
\hline
\end{tabular}

$\mathrm{GC}$ - the whole group of patients with anorexia nervosa (GC = GB + GA); GB - study group; GA - surveyed group 


\section{Education, gainful employment}

During the study, out of the entire investigated group, 57 women (average age: $21 \pm 3.4$ years) were still in education, with 24 women attending secondary school (23 in a general secondary school, 1 in a technical secondary school), and 33 were third-level students. Two study subjects did not provide information on their education in the survey; it was noted, therefore, that 38 women had completed their education (average age: $26 \pm 3.6)$. It was determined that 26 women $(68.4 \%)$ had a higher education degree, 8 (21\%) of whom $(21 \%)$ in 2 majors.

Among the women who had taken up studies, 23 women (39\%) had chosen humanities (according to frequency): language studies, tourism, pedagogy, psychology, history, political studies, law, or advertising. Other majors had been chosen by 36 women (61\%). They included medical and natural sciences, such as (according to frequency) the following: environmental protection, biotechnology, nursing, dietetics, pharmacy, biology, cosmetology, chemistry, and physical education. Economic and technical majors had been chosen by 18 women: economy, marketing and management, architecture, accounting, administration, mathematics, civil engineering, and graphic design.

Gainful employment had been taken up by a total of 39 women from the entire investigated group (IG). Within the group of 21 women still suffering from AN, 6 work professionally, with 1 woman working and studying at the same time and 1 woman still unemployed despite completing her education. The remaining 14 women were still in education.

\section{Family life}

$60.8 \%$ of women from the entire group (EG) have a partner, $15.4 \%$ of whom are married and $45.4 \%$ are in an informal rela- tionship. Out of the 76 cured women, $14 \%$ are married and $50 \%$ are in informal relationships. Out of the 21 women still suffering from AN, 19\% are married and 29\% are in informal relationships.

Twelve women (12.5\% of EG) have children: 8 women have 1 child, and 4 women have 2 children. In 9 women the course of pregnancy had been normal, and 3 reported unspecified complications during pregnancy.

Predictive factors

Based on the logit regression analysis, it was determined that the risk of persisting symptoms of the disease is 2.5 times higher in patients in whom the onset of AN had happened later, i.e. at the age of 18 years, as compared to patients who fell sick at the age of 12 years.

A statistically significant negative correlation between the age when the patient had fallen sick and the current BMI-SDS was confirmed in all the examined groups (EG, IG, SG), which may suggest that falling sick at an older age is associated with worse predictions as to body mass improvement. The highest statistical significance was demonstrated in the surveyed group ( $r=-0.374, p=0.0257$ ) (Fig. 1).

No significant links between the duration of the disease prior to hospitalisation, the duration and number of hospitalisations, and the recovery prognosis were confirmed.

An analysis of the nutritional status of girls suffering from AN at the onset of the disease based on Cole's ratio in the entire investigated group revealed a statistically significant positive correlation $(r=0.29, p=0.0318)$ between this parameter and the current BMI-SDS of the women examined after years (Fig. 2). On the other hand, BMI-SDS at the onset of the disease did not correlate with BMI-SDS after years in the entire studied group, but it correlated positively in the investigated group (IG; $r=0.246, p=0.0706$ ) and negatively in the surveyed group (SG; $r=-0.212, p=0.1831$ ) (Fig. 3).

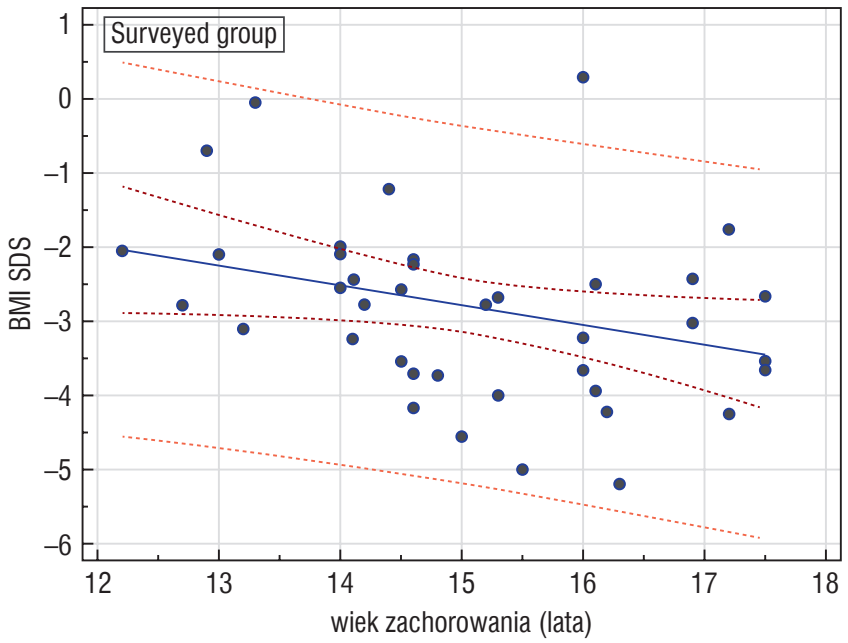

Figure 1. Correlation between the age of getting $\mathrm{AN}$ and BMISDS during adulthood in the surveyed group (GA); $r=-0.374$, $p=0.0257$

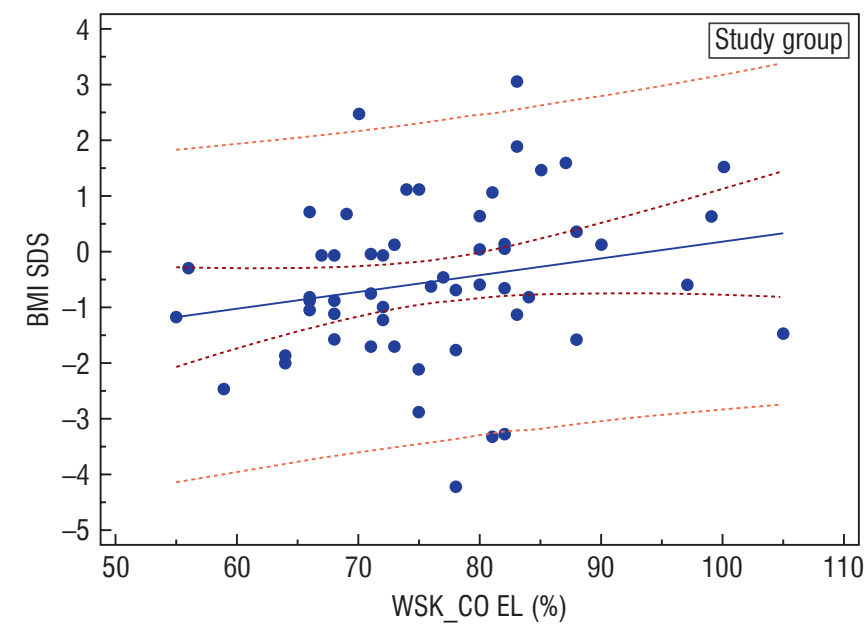

Figure 2. Correlation between Cole's index and BMI-SDS during adulthood in the study group (GB); $r=0.29, p=0.0318$ 


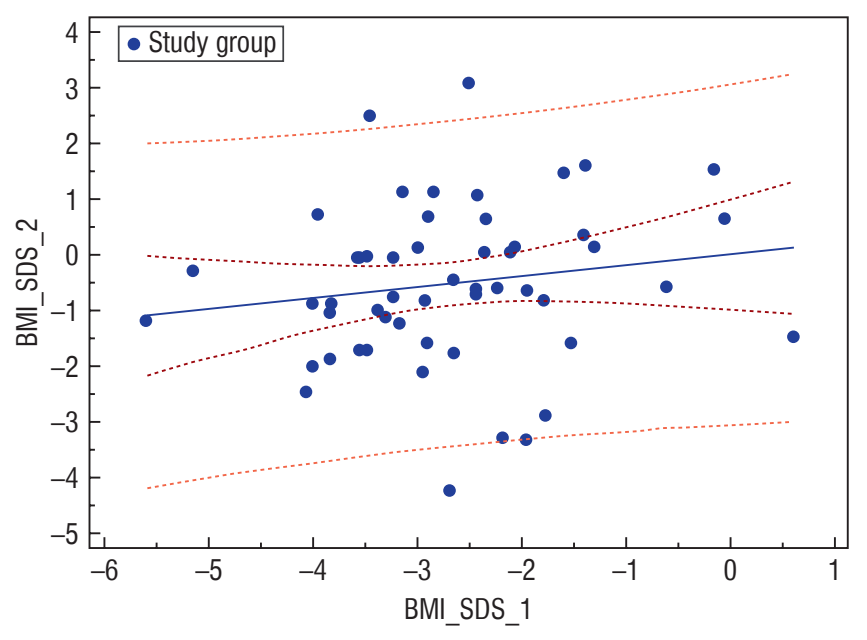

Figure 3. Correlation between BMI-SDS at the beginning of the disease and BMI-SDS after years in the investigated group (GB); $r=0.246, p=0.0706$

Our analysis also covered relations between the use of stimulants (cigarettes, alcohol, etc.) and the recovery prognosis. A slightly higher risk of a worse prognosis was demonstrated in the group of non-smokers $(O R=1.28, p=0.7242)$. None of the women in the investigated group reported alcohol abuse.

The study revealed that in the group of women who over time had been engaging in purging behaviours the risk of a worse recovery prognosis was significantly higher. In women who had been provoking vomiting this risk was 5.4 times higher $(p=0.0237)$, in women abusing laxatives it was 5.92 times higher $(p=0.0079)$, and in women using diuretics it was 8.1 times higher $(p=0.0521)$, in comparison to those who did not admit to any purging methods. There was no statistically significant link between consumption of herbal teas as a body mass reducing factor and the current condition of the examined women.

An analysis of the influence of family relations on the recovery prognosis revealed that the risk of persisting symptoms was 3.7 times higher $(p=0.3334)$ in the group of women who do not maintain regular contact with their mother.

When evaluating the relation between the parents' level of education and the recovery prognosis, it was observed that the risk of disease persistence is higher in patients whose mothers have secondary or vocational education and whose fathers have higher education.

\section{Discussion}

This study allowed us to assess treatment outcomes in 97 women treated in childhood for anorexia nervosa in our facility.

Like other authors $[10,16]$, we excluded males from our study due to their insufficient number. Firstly, the prevalence of AN among boys is lower than it is among girls. According to the DSM-IV criteria, the prevalence of AN in women is $1.2 \%$, whereas in men it is $0.29 \%$ [17], and under the DSM-5 criteria its prevalence in the population of 14-year-olds is estimated at $3.2 \%$ in girls and $1.6 \%$ in boys [18]. Boys are less likely than girls to go to paediatric hospital due to AN. It is suggested by our observations; boys were hospitalised 21 times less frequently than girls. Secondly, men are less willing to take part in studies, as shown by the fact that out of 9 men invited to the study, only 2 agreed to take part in it.

We had not planned a multicentre study; hence, the cohort of the study subjects, including men, is less numerous than in multicentre studies. We assessed further lives of only those women who had started treatment for anorexia nervosa in our facility.

The goal of the study was not to evaluate the treatment methods. We are aware of the fact that therapeutic strategies towards patients with eating disorders may differ significantly, depending on the country, residence (paediatric or psychiatric ward), the patient's age, duration of the treatment, developed methods of specialist care, frequency of follow-up appointments post hospitalisation, medications used, and psychotherapeutic interactions. For example, Japanese authors [13], who observed 41 girls with AN aged 8.6-15.6 years (mean age: 13.3) treated in a paediatric facility, observed that the average hospitalisation duration was much longer (130 days) than in hospitals in Western Europe and the USA. Such a long stay of a child in hospital allowed for simultaneous family therapy, which consisted of parents' meetings with an interdisciplinary team of specialists, individual therapy dedicated to families, and group therapy for parents [13].

What we tried to do was select a group of women as homogenous as possible, with the restricting type of AN diagnosed in childhood (AN-R). According to our observations, this type of $A N$ is much more frequent in adolescence than the binge-eating/purging type (AN-BP). Our study refers exclusively to women subjected to hospital treatment. Numerous authors, like us [6-8, 13, 16, 20], limited themselves to analysis of the course of AN exclusively in women who had been hospitalised due to this disease in childhood. Others evaluated long-term treatment results in patients subjected to in-patient as well as out-patient treatment $[10,11,21,22]$. Other authors compared experiences of women suffering from AN to the population of healthy women [23] or women who had suffered from other eating disorders in the past (bulimia, non-specific eating disorders) [7]. Swedish authors [12], on the other hand, evaluated AN treatment outcomes after 18 years [12] and then after 30 years [24], recruiting women to their study using the method of screening towards anorexia nervosa in 4291 subjects.

Methodologies and protocols of individual studies are different; hence, it is not possible to draw generalised conclusions as to long-term treatment results in patients suffering from anorexia nervosa. In such a homogenous cohort as ours, howev$\mathrm{er}$, the evaluation of treatment outcomes is valuable for us local therapists. We know these results refer exclusively to a small group of girls treated in our facility, according to the treatment strategy devised by us. 
The difficulty in objectifying long-term treatment outcomes resides also in the methods of obtaining data from study subjects. Numerous authors [12, 16, 20, 24-26], like us, developed their own questionnaires and surveys with questions addressed to study subjects, which constituted the main source of information on their experiences. The authors contacted study subjects by letter, phone, or via the Internet. Some investigators succeeded in obtaining information and details of the somatic and/or mental condition of study subjects during personal examinations performed by a general practitioner, a psychiatrist or a psychologist $[8,10,20]$. Some authors carried out standard psychological tests in order to objectify the assessment of the subjects' mental state or quality of life $[8,12,16,20,24,26]$.

We managed to examine personally nearly $58 \%$ of women recruited for the study, which allowed for an objective evaluation of their somatic state. The interval between hospitalisation in the clinic and the study reached 16.6 years for them, whereas in women who had not reported to the clinic personally but sent a completed survey, it reached 21 years.

The period of observation of anorexia nervosa treatment methods presented by different researchers varies: below 4 years, 4 to 10 years, 10 to 20 years, more than 20 years, and even 30 years $[7,9,15,24]$. The authors emphasise that it is not possible to investigate the lives of all patients, which due to different reasons, such as no access to address details due to a change of address, leaving Poland, impossibility of determining phone numbers, reluctance to take part in the study, or the patient's death. The share of individuals who respond to invitations to studies is different, and it may depend on the method of data acquisition, the time since hospitalisation, and the group size. For example, some authors [16] managed to obtain some feedback on the current condition from $75.1 \%$ patients, and others [10] from as many as 93\% patients. Patient data acquisition methods are diverse. Fichter et al. [16] obtained feedback on the patients' condition not only from them, but also from their GPs.

We sent invitations to the study directly to patients exclusively by post. We received no replies to nearly $46 \%$ of our letters, out of which $10 \%$ of our correspondence was returned due to a wrong address. Therefore, we obtained data from ca. $52 \%$ of women and ca. $22 \%$ of men.

Numerous researchers believe that anorexia nervosa is chronic in patients subjected to treatment as well as in the general population, i.e. in treated and untreated individuals [2].

In the group of women we studied who were subjected to hospital treatment, after ca. 8 years of observation we demonstrated that the recovery rate was $78.4 \%$, and $21.6 \%$ of women still suffered from anorexia nervosa. Similar results were provided by other authors after longer observation periods [5, 7].

Data on long-term results of treatment of AN in childhood provided in the literature are divergent. Steinhausen [14] in a meta-analysis of 119 works published in the second half of the $20^{\text {th }}$ century demonstrated that on average $46.9 \pm 19.7 \%$ (range: 0-92\%) of patients are chronically ill. Our observations as to the persistence of AN symptoms are similar, whereas the recovery rate amongst our patients was higher.
The advantage of our study was the fact that in more than half of the women we were able to verify their clinical condition and measure their body weight. Interestingly, it turned out that there were no significant differences in terms of the mean body mass, BMI, and BMI-SDS between the group investigated in the clinic and the surveyed group. Nevertheless, it cannot be ruled out that the body weight given by women who had not reported to the study within the facility was overstated.

The large differences in the evaluation of the course of the disease result from different criteria being applied in the definition of recovery, observation period, remission duration, clinical characteristics of the studied groups, and type of therapeutic methods [2]. Long-term observations present better results, in terms of complete recovery of AN patients, than the ones provided by Steinhausen [15] if individual clinical symptoms are considered. Body weight normalisation is observed in 59.6 $\pm 15.3 \%$ of patients, return of menstruation in $57.0 \pm 17.2 \%$, and normalisation of eating habits in $46.8 \pm 19.6 \%$ of subjects.

In the study of Couturier et al. [27] the time necessary to obtain improvement in terms of body weight in sick adolescent girls with AN was less than a year, but another year was necessary to obtain a psychological remission. During a 2-6-year observation the authors demonstrated that $94.4 \%$ of subjects experienced an increase in body weight up to $>85 \%$ of the standard body weight, in $90.5 \%$ menstruation returned, but any improvement in terms of mental state was observed only in $57.1 \%$ of the study subjects.

Definitions of a remission of anorexia nervosa have changed over the years, just like diagnostic criteria for eating disorders have been changing. This is due to an improved understanding of somatic, endocrine, and mental symptoms, the course of the disease, as well as nutritional behaviours in AN patients. One of the earlier definitions of remission of AN symptoms was a definition proposed in 1975 by Morgan H. and Russell G. [28]. The criteria of Morgan and Russel allow us to classify AN patients to 1 of 3 groups: 1. good outcome (weight within 15\% of average and normal, cyclical menstruation); 2. intermediate outcome (weight below $15 \%$ of average or menstrual irregularity); 3. poor outcome (weight below 15\% of average and menstruation absent or nearly absent or bulimia nervosa). Most researchers still apply Morgan-Russell criteria or use them after modifications introduced by other authors, e.g. Ratnasuriya et al. (1991), Jeammet et al. (1991), Strober et al. (1997), Löwe et al. (2001), and Eddy et al. (2017) [8-10, 16]. We followed the criteria of full and partial remission set forth in DSM-5 [1], although we also considered returned menstruation and no indications for further psychotherapy as signs of full recovery.

Strober et al. [5] in their prospective study lasting 10-15 years in 85 female patients hospitalised due to AN in adolescence demonstrated that these women needed 4.8-6.5 years (57-79 months) to obtain a full remission. A full remission according to the Morgan-Russell criteria occurred in most women $(58.9 \%)$ only 7 years after hospitalisation, and in $72.6 \%$ as late as 10 years after hospitalisation. In 10\% a partial remission was observed 2 years after hospitalisation, in $21 \%$ 3 years after hospitalisation, in $54.8 \%$ - 5 years after hospitali- 
sation, in $73.7 \%$ - 7 years after hospitalisation, and in $84.3 \%$ 10 years after hospitalisation.

On the other hand, Wentz et al. [12] in their prospective study of 51 patients (48 girls and 3 boys) suffering from AN in adolescence (average age: 14 years) selected during a screening towards eating disorders demonstrated that the average duration of AN was $3.4 \pm 2.4$ years (0.9-14.7 years). They concluded that a period of 10 years of observations of subjects treated for anorexia nervosa is sufficient in most cases.

Assuming that patients' hospitalisation testifies to a more severe course of the disease as compared to patients subjected to outpatient treatment, we analysed some of the relapses of the disease, assessing the percentage of re-hospitalisations. A vast majority of recovered patients (84.2\%) required only 1 stay in hospital, $10.5 \%-2$ hospitalisations, and $5.3 \%$ - 3 stays in hospital. The average hospitalisation time was 5 weeks. It can be concluded that the severity of symptoms of the disease in adolescence does not eliminate the chance of a full recovery.

A study conducted by Polish authors [29], like ours, after 8 years of observations of anorexia nervosa patients demonstrated a good outcome - according to the Morgan-Russell scale - of treatment in $75 \%$ of patients, which is a similar outcome to ours. An average outcome was confirmed in 11\%, and a bad outcome in $14 \%$. The percentage of re-hospitalisations in adolescence was much higher than in our patients, reaching $35 \%$, but it referred to the entire investigated group - both the recovered ones and the ones with only a partial remission or no remission at all. In contrast, we report several re-hospitalisations in women considered cured.

Zipfel et al. [19] in their 21-year long-term observations demonstrated that out of 84 teenage girls and young women hospitalised once, approximately half (50.6\%) recovered fully, and in $20.8 \%$ an improvement was noted. Nevertheless, $10.4 \%$ of these women were still chronically ill, and as many as $16.7 \%$ of them died.

Observations of patients subjected to intensive treatment in hospital demonstrates that there can be a deterioration in comparison to the improvement obtained in hospital within 2 years of discharge, but after 3-12 years a progressive improvement is noted [2].

On the basis of a literature review, Keel et al. [30] estimated that only a minority of patients hospitalised due to AN obtain remission, irrespective of whether the examination is carried out 2 or 12 years after hospitalisation. Most patients subjected to outpatient treatment, on the other hand, obtain a remission ca. 5 years after reporting for treatment. It may be assumed that some patients who do not require hospital treatment have a mild course of the disease.

Only a half of the women studied by us confirmed that after discharge they remained under the outpatient care of a physician in our facility. The average duration of follow-up visits was 15 months. We failed to determine with certainly what percentage of women remained under psychological and/or psychiatric care after discharge because relevant data were incomplete. It was estimated only indicatively that the duration of psychotherapy in the patients who provided us with data was 18 months on average: 9 months for recovered patients and 30 months in patients still suffering from AN. It turned out to be impossible to obtain sufficient information on specific mental disorders or psychotropic medications used. Unspecified mental disorders were reported by $10 \%$, half of which were still suffering from AN. We obtained information on suicidal attempts as many as $6.2 \%$ of the study subjects admitted to them. Women still suffering from $\mathrm{AN}$ reported twice as many suicidal attempts as women who had recovered.

According to Arcelus et al. [15], 1 in 5 AN patients who die has attempted suicide. The death rate in people with eating disorders is high. Together with AN cases, it is higher than death rates in mental disorders (schizophrenia, bipolar disorder, unipolar disorder).

Mortality rates for anorexia nervosa presented by different researchers are different. They depend on the group size, the characteristics of the investigated groups (general population or only hospitalised individuals), the observation period, the severity of disease, and the type of therapy applied.

Mortality rates for women who suffered from anorexia nervosa in childhood are divergent. In meta-analyses published by Steinhausen [14] (119 studies) and by Arcelus et al. [15] (36 studies) crude death rates (mortality rates in the studied groups) were between 0 and $22.5 \%$. On the other hand, the weighted mortality rates (deaths per 1000 person-years) for anorexia nervosa was 5.1, and the standardised mortality ratio (SMR - which quantifies the increase in mortality in a study population of the same age) was between 0 and 17.8 [15]. The SMR for suicidal death in AN ranges from 23.1 to 56.9 [32]. According to other authors [33] SMR is the highest amongst all psychiatric disorders.

Some authors [6, 8, 10, 12, 31], despite long-term observations, did not note any deaths caused by AN in women treated in childhood. This might result from the fact that patients treated in adolescence present a lower risk of death [2]. An analysis of national registers in Sweden covering patients treated in adolescence (1887-1993) demonstrated mortality related to anorexia nervosa at the level of $0.8 \%$, with a total mortality of $1.2 \%$, and the SMR was 3 [2]. A similarly low mortality rate (1\%) was noted in a group of patients in adolescence, covered with intensive medical care [2].

There were 2 deaths of teenage girls hospitalised in our facility, due to complications (gastric necrosis and catatonia in the first during the second hospitalisation in the clinic; heart rhythm disturbances at home in the second patient approx. 10 months after discharge). We did not include these deaths in our analysis - these patients were not covered in the study because they died in childhood.

According to the literature, worse course of the disease and higher mortality rate in AN occur in adults. A meta-analysis of a study on 2240 patients revealed that the AN-related mortality rate is 5.25\% and SMR 9.7 [34]. Another meta-analysis (12,189 patients) indicated an SMR of 5.85 for AN. Few deaths were recorded in the younger age group, but many in the group of individuals treated at the age of 20 years and 
over [15]. A higher mortality rate was associated with older age, low BMI, comorbidities (affective disorders, history of suicidal behaviours, self-harm, alcohol abuse), and hospitalisation due to other mental disorders.

Our study demonstrated that the risk of persisting AN symptoms is 2.5 times higher in patients in whom the onset of the disease had occurred at a later age (age 18 years) than in younger patients (age 12 years), and older age at the onset of the disease is associated with a worse prognosis regarding body weight improvement. Most authors have had similar observations. The meta-analysis of Steinhausen [14] confirmed that better recovery results are observed in adolescents in comparison to adolescents and adults studied together (good treatment outcomes occurred in $57.1 \pm 15 \%$ vs. $44.2 \pm 21.8 \%$, respectively, and a chronic course in $16.9 \pm 7.5 \%$ vs. $23.5 \pm 14.9 \%$, respectively). Recovery prognosis is worse if the disease begins in childhood, before adolescence [14], but a good parent-child relationship can protect the patient from a bad outcome of the disease.Wentz et al. [12] also believe that a younger age at the onset of the disease does not foster a better prognosis in AN. On the basis of their research, they demonstrated that features of obsessive-compulsive personality and features of pervasive developmental disorders occurring prior to the disease constitute an unfavourable predictor.

Bryant-Waugh et al. [35], on the basis of their observations, claim that a young age at the onset of the disease $(<11)$, depression in the course of the disease, family conflicts, having only 1 parent, or another marriage of one of the parents before falling ill constitute bad predictive factors. Bad prognosis for patients with a very early onset of AN was also confirmed in another study (age 8-14 years) [36].

According to other researchers, negative predictive factors are the severity of AN symptoms entailing the need of hospitalisation and a longer duration of the disease prior to hospitalisation [2]. We did not confirm these observations. There were no links between the duration of the disease prior to hospitalisation, the duration of hospital treatment, and the number of hospitalisations

We did demonstrate, however, an increased risk of a worse prognosis in women who in the course of the disease additionally presented with binge-eating/purging symptoms. In vomiting women the risk was 5.4 times higher, in women abusing laxatives - 5.92 times higher, and in women using diuretics 8.1 times higher than in women who did not admit to using any purging methods. This was also confirmed in a meta-analysis of a study carried out in 5590 patients suffering from AN, performed by Steinhausen [14].

Obsessive-compulsive disorder (OCD) and/or the obsessive-compulsive personality disorder (OCPD) or the autism spectrum disorder (ASD) accompanying AN also have a negative effect on the course of the disease. Polish authors [37] who studied 76 girls with AN aged $14.8 \pm 1.8$ years demonstrated that the presence of OCD symptoms in them was associated with excessive physical activity, which increased the risk of faster weight loss. They concluded that it was advisable to consider the implementation of additional methods in this group of patients to reduce obsessive-compulsive symptoms. Histrionic personality disorder, on the other hand, is associated with a better prognosis [14].

Numerous investigators emphasise that good preparation to social life in the period preceding the onset of the disease, a short period of persistence of symptoms prior to treatment, quick implementation of treatment, a short hospitalisation period, and higher socioeconomic status are associated with a better prognosis [14].

A good parent-child relationship may protect the patient against a poor outcome [14]. We demonstrated that the risk of persisting symptoms of the disease was 3.7 times higher in the group of women who did not maintain regular contacts with their mothers. We also observed that the risk of persistence of the disease was higher in women whose mothers had secondary or vocational education and fathers with higher education.

Other authors $[16,20,23]$ evaluated - as we did - sociodemographic factors, such as education, employment, marriage, and fertility. The study by Mustelin et al. [23] demonstrated that women with AN were better educated (38\% were in higher education) as compared to women who did not suffer from AN (29\% in higher education), despite frequent absences caused by the disease. The authors believe that women with AN are in education longer, study, and complete postgraduate courses as a form of readaptation to the society. Out of the women with AN studied by us, $68.4 \%$ had higher education, with $21 \%$ of them in 2 majors.

Amongst women with AN studied by the aforementioned authors [23], $68 \%$ were married, as compared to $78 \%$ of women without AN. Only a half of women with AN had children, in comparison to $66 \%$ of healthy women. Out of women with AN who did not have a child, $10 \%$ (vs. $6 \%$ of healthy women) were currently pregnant, $16 \%$ had had a spontaneous miscarriage (vs. $8 \%$ of healthy women), and $21 \%$ (vs. $9 \%$ of healthy women) had had an abortion.

Fichter et al. [16] found that $27.4 \%$ women with AN had one or more children, and maternity was associated with a better treatment outcome. On the other hand, Löwe et al. [20] demonstrated that out of 63 women with anorexia nervosa $71.4 \%$ were married, $68.3 \%$ had offspring, and $71.4 \%$ were fit for gainful employment. Out of 8 women who had not been cured, only 3 were married (37.5\%) and 2 had offspring (25\%). Only 2 were fit for gainful employment (25\%).

In the entire group we studied, almost $61 \%$ had a partner, with most women in an informal rather than a formal relationship (45.4\% vs. 15.4\%). Out of 21 women still suffering from AN, $19 \%$ were married and $29 \%$ were involved in an informal relationship. The percentage of women who had children in the entire group was $12.5 \%$. We are aware that these results are not final because these data may change in the long run.

We also realise our study had certain limitations. We conducted the study only in the group of women who had been hospitalised in the past in the paediatric ward. This group comprises patients who were seriously ill somatically, with the exclusion of AN patients subjected to outpatient treatment. We also did not examine AN patients with concomitant severe mental 
disorders because such patients are referred directly to psychiatric wards. We did not include in our study patients with a binge-eating/purging type of anorexia because it would have been difficult to compare treatment outcomes for 2 groups of patients differing in terms of size. We know from experience that this type of anorexia is much less frequent in childhood.

We did not evaluate the mental state of our patients in any objective manner because it did not constitute the subject matter of our study. We were interested in long-term experiences of our patients and their somatic condition. Additionally, we directed our study towards an assessment of the hormonal function of gonads and mineral density of bones, but the results we obtained constitute a subject matter of another study, currently being prepared for publication.

Our study is not a multicentre one. Nevertheless, there are not many paediatric wards in Poland organised like ours, which offer comprehensive therapies to children and adolescents suffering from anorexia nervosa. Scientific cooperation with psychiatric wards to which our adult patients might have been admitted due to a relapse of AN or exacerbation of AN symptoms could have provided us with more valuable information on their lives and course of treatment. This was, however, difficult in terms of organisation.

More information could also have been obtained if this study had been prospective. However, it is extremely difficult to obtain consent from the patients themselves to investigate their

\section{References}

1. American Psychiatric Association. Diagnostic and Statistical Manual of Mental Disorder (DSM V) AP. Washington DC 2013.

2. Jagielska G, Kacperska I. Outcome, comorbidity and prognosis in anorexia nervosa. Psychiatr Pol 2017; 51: 205-218. doi: 10.12740/ $\mathrm{PP} / 64580$

3. Hoek HW. Incidence, prevalence and mortality of anorexia nervosa and other eating disorders. Curr Opin Psychiatr 2006; 19: 389-394. doi: 10.1097/01.yco.0000228759.95237.78.

4. Herpertz-Dahlmann B. Adolescent eating disorders: definitions, symptomatology, epidemiology and comorbidity. Child Adol Psych Cl 2008; 18: 31-47. doi: 10.1016/j.chc.2014.08.003.

5. Strober M, Freeman R, Morrell W. The long-term course of severe anorexia nervosa in adolescents: Survival analysis of recovery, relapse, and outcome predictors over 10-15 years in a prospective study. Int J Eat Disord 1997; 22: 339-360. doi: 10.1002/(sici)1098108x(199712)22:4<339::aid-eat1>3.0.co;2-n.

6. Saccomani L, Savoini M, Cirrincione M, et al. Long-term outcome of children and adolescents with anorexia nervosa: study of comorbidity. Psychosomat Res 1998, 44: 565-571. doi: 10.1016/s00223999(97)00210-9.

7. Steinhausen HC, Seidel R, Winkler Metzke C. Evaluation of treatment and intermediate and long-term outcome of adolescent eating disorders. Psychol Med 2000; 30: 1089-1098. doi: 10.1017/ s0033291799002354.

8. Herpertz-Dahlmann B, Muller B, Herpertz S, et al. Prospective 10-year follow-up in adolescent anorexia nervosa: Course, outcome, lives later. Both the patients and their parents wish to forget the traumatic memories associated with the disease and hospitalisation. Frequently they are also reluctant to admit to having had AN in their youth.

Our analysis of long-term treatment outcomes and better knowledge of the course of AN with reference even to this narrow group of girls suffering from AN selected by us seems to be valuable. It may prove helpful for physicians and therapists in determining the recovery prognosis and further lives of these patients.

\section{Conclusions}

Most girls suffering from the restricting type of anorexia nervosa in adolescence recover fully.

The severity of symptoms in such girls does not eliminate the chance of recovering and achieving important life goals, such as completing education, finding a life partner, and having offspring.

Girls with a lower degree of cachexia at the onset of the disease, with no binge-eating / purging symptoms, maintaining regular contact with their mother, can count on better recovery prognosis.

Ca. $6 \%$ of women treated for anorexia nervosa in their youth face the risk of a suicidal attempt, which points to the necessity to monitor the mental state of these women for many years.

psychiatric comorbidity, and psychosocial adaptation. J Child Psychol Psychiatry 2001; 42: 603-612.

9. Wentz E, Gillberg C, Gillberg IC, Råstam M. Ten-year follow-up of adolescent-onset anorexia nervosa; psychiatric disorders and overall functioning scales. J Child Psychol Psychiatr 2001; 42: 613-622.

10. Halvorsen I, Andersen A, Heyerdahl S. Good outcome of adolescent onset anorexia nervosa after systematic treatment. Eur Child Adolesc Psychiatr 2004; 13: 295-306. doi: 10.1007/s00787-0040408-9.

11. Nilsson K, Häglöf B. Long-term follow-up of adolescent onset anorexia nervosa in northern Sweden. Eur Eat Disord Rev 2005; 13: 89.

12. Wentz E, Gillberg IC, Anckarsater H, et al. Adolescent-onset anorexia nervosa: 18-year outcome. Br J Psychiatry 2009; 194: 168174. doi: 10.1192/bjp.bp.107.048686.

13. Tasaka K, Matsubara K, Takamiya S, et al. Long-term follow up of hospitalized pediatric anorexia nervosa restricting type. Pediatr Int 2017; 59: 482-414. doi: 10.1111/ped.13194.

14. Steinhausen HC. The outcome of anorexia nervosa in the 20th century. Am J Psychiatr 2002, 159: 1284-1293. doi: 10.1176/appi. ajp.159.8.1284.

15. Arcelus J, Mitchell AJ, Wales J, Nielsen S. Mortality rates in patients with anorexia nervosa and other eating disorders. A meta-analysis of 36 studies. Arch Gen Psychiatr 2011, 68:724-731. doi: 10.1001/ archgenpsychiatry.2011.74.

16. Fichter MM, Quadflieg N, Crosby RD, Koch S. Long-term outcome of anorexia nervosa: Results from a large clinical longitudinal study. Int J Eat Disord 2017; 50: 1018-1030. doi: 10.1002/eat.22736 
17. Bulik CM, Sullivan PF, Tozzi F, et al. Prevalence, heritability, and prospective risk factors for anorexia nervosa. Arch Gen Psychiatr 2006; 63: 305-312. doi: 10.1001/archpsyc.63.3.305.

18. Micali N, Solmi F, Horton NJ, et al. Adolescent eating disorders predict psychiatrc, high-risk behaviours and weight outcome in young adulthood. J Am Acad Child Psych 2015; 54: 652-659. doi: 10.1016/j.jaac.2015.05.009.

19. Zipfel S, Löwe B, Reas DL, et al. Long-term prognosis in anorexia nervosa: lessons from a 21-year follow-up study. Lancet 2000; 355 721-722. doi: 10.1016/S0140-6736(99)05363-5.

20. Löwe B, Zipfel S, Buchholz C, et al. Long-term outcome of anorexia nervosa in a prospective 21-year follow-up study. Psychol Med 2001; 31: 881-890. doi: 10.1017/s003329170100407x.

21. Hsu LK, Crisp AH, Harding B. Outcome of anorexia nervosa. Lancet 1979; 1: 61-65. doi: 10.1016/s0140-6736(79)90060-6.

22. Franko DL, Keshaviah A, Kamryn TE, et al. Do mortality rates in eating disorders change over time? A longitudinal look at anorexia nervosa and bulimia nervosa. Am J Psychiatry 2013; 170: 917-925.

23. Mustelin L, Raevuori A, Bulik C, et al. Long-term outcome in anorexia nervosa in the community. Int J Eat Disord 2015; 48: 851-859. doi: 10.1002/eat.22415

24. Dobrescu SR, Dinkler L, Gillberg C, et al. Anorexia nervosa: 30-year outcome. Brit J Psychiatr 2020; 216: 97-104. doi: 10.1192/ bjp.2019.113

25. Errichiello L, lodice D. Bruzzese D, et al. Prognostic factors and outcome in anorexia nervosa: follow-up study. Eat Weight Disord 2016; 21: 73-82. doi: 10.1007/s40519-015-0211-2.

26. Sunday SR, Reeman IM, Halmi KA. Ten-year outcome in adolescent onset anorexia nervosa. J Youth Adolesc 1996; 25: 533-544.

27. Couturier J, Lock J. What is recovery in adolescent anorexia nervosa. Int J Eat Disord 2006; 39: 550-555. doi: 10.1002/eat.20309.

28. Morgan HG, Russell GF. Value of family background and clinical features as predictors of long-term outcome in anorexia nervosa: four-year follow-up study of 41 patients. Psychol Med 1975; 5: 355371. doi: 10.1017/s0033291700056981.

29. Komender J, Popielarska A, Tomaszewicz-Libudzic C, et al. Odległe wyniki leczenia dorastających chorych na jadłowstręt psychiczny. Psychiatr Pol 1998; 32: 759-769.

30. Keel PK, Brown TA. Update on course and outcome in eating disorders. Int J Eat Disord 2010; 43: 195-204. doi: 10.1002/eat.20810.

31. Råstam M, Gillberg C. Wentz E. Outcome of teenage-onset anorexia nervosa in Swedish community-based sample. Europ Child Adolesc Psychiatry 2003; 12 suppl 1: 78-90. doi: 10.1007/s00787003-1111-y.

32. Papadopoulos FS, Ekbom A, Brandt L, Ekselius L. Excess mortality, causes of death and prognostic factors in anorexia nervosa. Brit J Psychiatr 2009; 194: 10-17. doi: 10.1192/bjp.bp.108.054742.

33. Klump KL, Bulik CM, Kaye WH, et al. Academy for eating disorders position paper: eating disorders are serious mental illnesses. Int J Eat Disorder 2009; 42: 97-103. doi: 10.1002/eat.20589.

34. Signorini A, De Filippo E, Panico S, et al. Long-term mortality in anorexia nervosa: a report after 8-year follow-up and review of the most recent literature. Eur J Clin Nutr 2007; 61: 119-122. doi: 10.1038/sj.ejcn.1602491.

35. Bryant-Waugh B, Knibbs J, Fosson A, et al. Long term follow up of patients with early onset anorexia nervosa. Arch Dis Child 1988; 63: 5-9.

36. Lask B, Bryant-Waugh B. Early-onset anorexia nervosa and related eating disorders. J Child Psychol Psych 1992; 33: 281-300. doi: 10.1002/eat.20163.

37. Błachno M, Bryńska A, Tomaszewicz-Libudzic C, et al. The influence of obsessive symptoms on the course of anorexia nervosa. Psychiatr Pol 2014; 48: 429-439. 